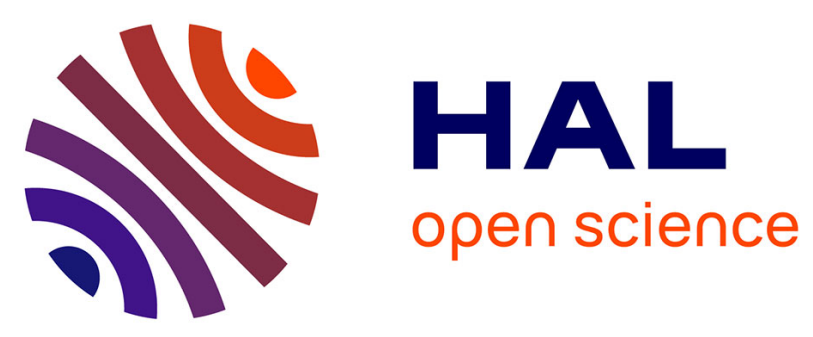

\title{
SFE/SFHTA/AFCE consensus on primary aldosteronism, part 6: Adrenal surgery
}

Olivier Steichen, Laurence Amar, Philippe Chaffanjon, Jean-Louis Kraimps, Fabrice Ménégaux, Franck Zinzindohoue

\section{- To cite this version:}

Olivier Steichen, Laurence Amar, Philippe Chaffanjon, Jean-Louis Kraimps, Fabrice Ménégaux, et al.. SFE/SFHTA/AFCE consensus on primary aldosteronism, part 6: Adrenal surgery. Annales d'Endocrinologie, 2016, 77 (3), pp.220-225. 10.1016/j.ando.2016.01.009 . hal-01358895

\section{HAL Id: hal-01358895 \\ https://hal.sorbonne-universite.fr/hal-01358895}

Submitted on 1 Sep 2016

HAL is a multi-disciplinary open access archive for the deposit and dissemination of scientific research documents, whether they are published or not. The documents may come from teaching and research institutions in France or abroad, or from public or private research centers.
L'archive ouverte pluridisciplinaire HAL, est destinée au dépôt et à la diffusion de documents scientifiques de niveau recherche, publiés ou non, émanant des établissements d'enseignement et de recherche français ou étrangers, des laboratoires publics ou privés.

\section{(1) (1) $\$$}

Distributed under a Creative Commons Attribution - NonCommercial - NoDerivatives| 4.0 


\title{
SFE/SFHTA/AFCE consensus on primary aldosteronism, part 6: Adrenal surgery
}

\author{
Consensus hyperaldostéronisme primaire SFE/SFHTA/AFCE, groupe 6: Chirurgie surrénale \\ Olivier Steichen $^{\mathrm{a}, \mathrm{b}, *}$, Laurence Amar ${ }^{\mathrm{c}, \mathrm{d}}$, Philippe Chaffanjon ${ }^{\mathrm{e}, \mathrm{f}}$, Jean-Louis Kraimps ${ }^{\mathrm{g}, \mathrm{h}}$, \\ Fabrice Ménégaux ${ }^{b, i}$, Franck Zinzindohoue ${ }^{\mathrm{d}, \mathrm{j}}$ \\ ${ }^{a}$ Service de médecine interne, hôpital Tenon, AP-HP, 75020 Paris, France \\ ${ }^{\mathrm{b}}$ Sorbonne universités, UPMC université Paris 06, faculté de médecine, 75006 Paris, France \\ ${ }^{\mathrm{c}}$ Unité d'hypertension artérielle, AP-HP, HEGP, 75015 Paris, France \\ d Sorbonne Paris Cité, université Paris Descartes, faculté de médecine, 75006 Paris, France \\ ${ }^{\mathrm{e}} \mathrm{CHU}$ Grenoble, département de chirurgie thoracique, vasculaire et endocrinienne, 38700 La Tronche, France \\ ${ }^{\mathrm{f}}$ Laboratoire d'anatomie des Alpes françaises (LADAF), université Grenoble Alpes, UFR de médecine, 38700 La Tronche, France \\ ${ }^{g}$ Chirurgie générale et endocrinienne, hôpital Jean-Bernard, CHU de Poitiers, 86000 Poitiers, France \\ ${ }^{\mathrm{h}}$ Faculté de médecine, université de Poitiers, 86000 Poitiers, France \\ i Service de chirurgie digestive et viscérale, AP-HP, Pitié-Salpétrière, 75013 Paris, France \\ j Service de chirurgie digestive, générale et cancérologique, AP-HP, HEGP, 75015 Paris, France
}

\begin{abstract}
Treatment of primary aldosteronism (PA) aims at preventing or correcting hypertension, hypokalemia and target organ damage. Patients with lateralized PA and candidates for surgery may be managed by laparoscopic adrenalectomy. Partial adrenalectomy and non-surgical ablation have no proven advantage over total adrenalectomy. Intraoperative morbidity and mortality are low in reference centers, and day-surgery is warranted in selected cases. Spironolactone administered during the weeks preceding surgery controls hypertension and hypokalemia and may prevent postoperative hypoaldosteronism. In most cases, surgery corrects hypokalemia, improves control of hypertension and reduces the burden of pharmacologic treatment; in about $40 \%$ of cases, it resolves hypertension. However, success in controlling hypertension and reversing target organ damage is comparable with mineralocorticoid receptor antagonists. Informed patient preference with regard to surgery is thus an important factor in therapeutic decision-making.
\end{abstract}

(C) 2016 Elsevier Masson SAS. All rights reserved.

Keywords: Adrenalectomy; Hyperaldosteronism; Treatment outcome; Guiding factors

\section{Résumé}

Le traitement de l'hyperaldostéronisme primaire vise à prévenir ou corriger l'hypertension, l'hypokaliémie et le retentissement direct sur les organes cibles. Les patients avec une hypersécrétion latéralisée d'aldostérone et candidats à la chirurgie peuvent bénéficier d'une surrénalectomie laparoscopique. La surrénalectomie partielle et les ablations non chirurgicales n'ont pas d'avantage avéré par rapport à la surrénalectomie totale. La morbimortalité peropératoire est faible dans les centres de référence, autorisant la chirurgie ambulatoire dans des cas sélectionnés. L'administration de spironolactone dans les semaines précédant la chirurgie permet de contrôler l'HTA et l'hypokaliémie, et peut-être de prévenir l'hypoaldostéronisme postopératoire. Dans la plupart des cas, la chirurgie corrige l'hypokaliémie, améliore le contrôle de la pression artérielle et diminue la charge des traitements pharmacologiques; dans environ $40 \%$, elle guérit l'hypertension. Toutefois, le contrôle de l'hypertension et la réversibilité du retentissement sur les organes cibles sont comparables avec les antagonistes du récepteur des minéralocorticoïdes. Les préférences du patient pour ou contre la chirurgie sont donc un élément important de la décision thérapeutique, après information éclairée.

(C) 2016 Elsevier Masson SAS. Tous droits réservés.

Mots clés : Surrénalectomie ; Hyperaldostéronisme ; Résultat thérapeutique ; Lignes directrices

\footnotetext{
* Corresponding author. Service de médecine interne, hôpital Tenon, 4, rue de la Chine, 75020 Paris, France.

E-mail address: olivier.steichen@tnn.aphp.fr (O. Steichen).
} 
This section deals with adrenalectomy in lateralized primary aldosteronism (PA). Indications depend on the risk/benefit profile in comparison with medical management, and on patient preference and overall cost considerations between the two approaches.

\section{Adrenal surgery in PA}

\subsection{Technical aspects}

\subsubsection{Open or laparoscopic surgery}

Except for adrenocortical carcinoma, which is exceptional, the adrenal lesions causing lateralized PA are small and benign, making them ideal for laparoscopic surgery [1]. Laparoscopic adrenalectomy entails fewer perioperative complications (parietal, infectious, respiratory or cardiovascular) than open surgery and allows shorter hospital stay [2].

R6.1 - When surgery is indicated, laparoscopic rather than open surgery is recommended.

(Strong, evidence +++ )

\subsubsection{Laparoscopic approach}

The lateral transperitoneal approach provides better operative site exposure, while posterior retroperitoneoscopy avoids the problems of adherences from previous surgeries and may reduce hospital stay [3]. Laparoscopic adrenalectomy usually requires 3 or 4 entry points, although an isolated transumbilical approach is also possible and less invasive [4].

Robot-assisted surgery is possible and without added risk, but expensive and without proven benefit over simple laparoscopic surgery [5-7].

R6.2 - We recommend a trans- or retroperitoneal approach, with or without robotassistance, according to the patient's profile and the surgeon's preferences.

(Strong, evidence ++ )

\subsubsection{Total or partial adrenalectomy}

Adenomectomy is possible and entails no extra complications compared to total adrenalectomy [8,9]. Operative times are similar, although intraoperative blood loss is significantly greater in adenectomy, without, however, requiring supplementary transfusion $[8,9]$. The rationale supporting conservative surgery, however, is unclear in lateralized PA, which never shows recurrence in the contralateral adrenal; moreover, 10-25\% of patients have several adjacent nodules, whether or not visible on preoperative imaging, and there is no way of knowing which is responsible for the PA, entailing a risk of incomplete treatment if part of the adrenal is spared [10].
R6.3 - Except in special cases, total adrenalectomy is indicated in lateralized PA.

(Weak, evidence + )

\subsection{General complications}

Mean operative time, in a specialized center with an experienced surgeon, is $1-2 \mathrm{~h}[11,12]$, with cross-over to open surgery never more than 5\% [1]. Perioperative mortality is less than $0.5 \%$, and perioperative morbidity ranges between 5 and $15 \%$, mainly comprising minor complications: transient parietal hypotonia or hypoesthesia $[1,2,11]$. Severe complications (hemorrhage requiring transfusion, cardiac or respiratory complications) concern less than $2 \%$ of cases $[1,2,11]$. However, the complications rate depends or the surgical team's experience, and higher severe complications rates were reported outside of specialized centers [13].

R6.4 - Adrenalectomy should be performed by an experienced surgeon in a reference center. (Weak, evidence + )

In specialized centers, mean hospital stay is 3 days [1]. Given the low risk of complications in such centers, laparoscopic adrenalectomy may be performed on an outpatient basis in well-selected cases: age $<65$ years, without significant cardiac comorbidity, hypertension managed by at most 3 drugs, procedure performed early in the day, and residence within $30 \mathrm{~min}$ of the hospital [14-16].

R6.5 - In references centers, selected patients may be managed on an outpatient basis.

(Weak, evidence ++ )

\subsection{Specific complications and short-term follow-up}

Systolic pressure increases by a mean $20-30 \mathrm{mmHg}$ above usual levels during laparoscopic adrenalectomy for lateralized PA, requiring antihypertensive treatment in $45 \%$ of cases [17]. Without potassium supplementation, kalemia diminishes by a mean $0.5-1 \mathrm{mmol} / \mathrm{l}$ during adrenalectomy compared to preoperative values [18], and kalemia should therefore be normalized just ahead of surgery. Spironolactone during the weeks before surgery may also reduce the risk of postoperative hyperaldosteronism by neutralizing aldosterone inhibition in the normal adrenal. 
R6.6 - We recommend preoperative mineralocorticoid receptor antagonist treatment to control hypertension and hypokalemia and reduce the risk of postoperative functional mineralocorticoid insufficiency. Preoperative potassium supplementation is recommended in case of persistent hypokalemia.

(Strong, evidence + )

Postoperative hyperkalemia due to functional mineralocorticoid insufficiency in the contralateral adrenal was nevertheless reported in 15-30\% of cases despite preventive prescription of preoperative spironolactone $[19,20]$. It was generally moderate and transient. Spironolactone and potassium supplementation should be interrupted at surgery to reduce this risk, and kalemia should be checked postoperatively, especially in case of chronic kidney failure [20]. Even so, however, up to 5\% of patients may require prolonged postoperative fludrocortisone treatment [19].

R6.7 - Mineralocorticoid receptor antagonists and potassium supplementation should be interrupted at surgery to avoid hyperkalemia induced by functional mineralocorticoid insufficiency. We also recommend interrupting low-salt diet and antihypertensives in the absence of other indications, to reduce the risk of fall in blood pressure due to functional mineralocorticoid insufficiency. (Strong, evidence +)

R6.8 - Blood pressure and kalemia should be monitored postoperatively. Antihypertensive treatment should be resumed in case of postoperative hypertension. Fludrocortisone should be administered in case of persistent symptomatic hyperkalemia or hypotension.

(Strong, evidence +)

\subsection{Medium-to-long-term follow-up}

Postoperative distinctions between histological types of PA are without clinical impact, but may be contributive epidemiologically. In persistent postoperative hypertension or hypokalemia, hormonal analysis may diagnose persistent PA and guide further treatment. If hypertension and hypokalemia have resolved, there is no individual benefit of hormonal analysis, although it may be useful for objectively assessing cure. Patients with normal blood pressure and kalemia at 1 year without treatment can be deemed cured.
R6.9 - Postoperative hormone analysis is recommended in case of persistent hypertension or hypokalemia, and suggested in case of clinical and biological cure of PA.

(Evidence + )

R6.10 - Specific clinical and biological followup should be ceased in patients with normal blood pressure and kalemia at 1 year without treatment. In case of persistent hypertension, follow-up should be conducted according to postoperative diagnosis: essential hypertension or persistent PA.

(Weak, evidence + )

\section{Surgical outcomes in lateralized PA}

Surgical outcomes assessment was based on a systematic review of series of more than 50 patients; only those published since 2000 were included, so as to represent the outcomes of laparoscopic surgery in present-day patients [10]. Older series concerned open surgery, and patients differed from recent series as hypertension was defined by an outdated threshold of $>160 / 100 \mathrm{mmHg}$ and the aldosterone-to-renin ratio was not used in screening. The limitations of the included series were that they did not compare surgical versus medical treatment, and assessed outcomes only in the medium term (a few months to a few years).

\subsection{Hyperaldosteronism and hypokalemia}

By definition, unilateral adrenalectomy cures hyperaldosteronism in all cases of lateralized PA. In practice, 5-10\% of operated patients show persistent hyperaldosteronism, as their PA was non-lateralized [10]. Misdiagnosis of lateralization is thus possible, even with adrenal vein sampling [21]; the frequency may be overestimated, as postoperative hormonal assay is often restricted to patients not showing the expected clinical benefit from surgery. Hypokalemia resolved in more than $95 \%$ of cases in all series [10].

\subsection{Blood pressure}

Cure rates for hypertension are around $40 \%$, with wide variation between series [10]. Patients who are not actually cured generally show considerable postoperative improvement, with significant reductions in blood pressure $(20-40 \mathrm{mmHg}$ for systolic BP) and medication (reduction of 1-2 therapeutic classes). The proportion of patients without obvious benefit ranges between 0 and $25 \%$.

Numerous predictive factors have been suggested for persistent postoperative hypertension [10]. Factors emerging as significant from at least 1 multivariate analysis comprise male gender, age, familial history of hypertension, duration of hypertension, 
blood pressure elevation requiring a larger number of treatments, elevated body-mass index, elevated kalemia, low glomerular filtration rate, elevated urinary aldosterone divided by plasma renin concentration, and infraclinical target organs damage.

These prognostic factors, however, are of very little relevance to selection for surgery $[10,22]$. Firstly, studies lacked power and showed poor reproducibility. Secondly, the difference in success rates associated with these factors was low, even when statistically significant: typically, patients with multiple factors of poor prognosis still had a $25 \%$ chance of complete cure by surgery, compared to $40 \%$ in the overall population. Thirdly, those whose hypertension was not cured nevertheless showed considerably reduced blood pressure and/or medication [23]. And fourthly, there may be benefit regardless of blood pressure reduction, as normalized aldosterone secretion benefits target organs.

There have been no studies directly comparing bloodpressure impact between adrenalectomy and medical treatment in lateralized PA. One study, however, suggested that kalemia normalization and blood-pressure reduction are comparable between spironolactone treatment and surgery, even in the long term [24].

\subsection{Cardiovascular, renal and metabolic impact}

\subsubsection{Infraclinical cardiovascular damage}

Many studies reported that left ventricle hypertrophy regressed after adrenalectomy. Those with long-term followup suggested that spironolactone provided the same effect, but more slowly [25]. Likewise, pulse-wave velocity and carotid intima-media thickness, which are increased in PA, improved after surgery $[26,27]$ and spironolactone again provided the same benefit, but more slowly [28].

\subsubsection{Cardiovascular events}

A long-term prospective study compared 54 PA patients managed surgically (unilateral PA) or medically (uni- or bilateral PA) and 323 matched essential hypertension patients. Incidence did not differ for the composite endpoint of myocardial infarction, coronary revascularization, stroke or sustained arrhythmia at a mean 7.4 years' follow-up between PA and essential hypertension or between PA managed by surgery or by spironolactone [29]. A similar study used a slightly different composite endpoint of acute coronary event, persistent arrhythmia or hospital admission for heart failure; incidence over a mean 12 years' follow-up was slightly greater in $270 \mathrm{PA}$ patients with specific surgical or medical treatment than in 810 matched essential hypertension patients [30]. The differing result may have been due to the inclusion of hospital admissions for heart failure, unlike in the previous study.

\subsubsection{Infraclinical renal damage}

Relative glomerular hyperfiltration and microalbuminuria in PA are reversible after surgery or spironolactone treatment [31]. A short-term (1 year) study suggested superiority of surgery over medical treatment with regard to glomerular filtration rate and proteinuria [32]. However, long-term ( $>5$ years) renal benefit of medical treatment seems not inferior to surgery [33-35].

\subsubsection{Metabolic impact}

There are arguments pointing to insulin resistance in PA, reversible with specific treatment. The clinical studies, however, demonstrate neither increased prevalence of lipid or glucose metabolism disorder nor improvement with PA-specific treatment [36-38].

\subsection{Quality of life/satisfaction}

One study reported that the impaired quality of life of unilateral PA patients was improved by adrenalectomy [39]. Spironolactone seems to have the same effect, at a longer term, on all forms of PA [40].

\subsection{Treatment costs}

A rough cost/benefit analysis showed that, in 50 year-old unilateral PA patients, adrenalectomy was more economical in cost terms than life-long medication, if it achieved $35 \%$ cure of hypertension and 50\% improvement in control [41]. Another analysis suggested that adrenal vein sampling followed by surgery when PA proved lateralized was less expensive than systematic medical treatment without adrenal vein sampling, when life expectancy exceeded 25 years; the model's hypotheses, however, were open to criticism, with a high proportion of unilateral PA $(50 \%)$ in patients undergoing adrenal vein sampling, an optimistic rate of hypertension cure (48\%) and higher costs than would be applicable in France: $\$ 330$ per year for spironolactone $75 \mathrm{mg}, \$ 2200$ for adrenal vein sampling, and $\$ 8400$ for surgery [42].

\section{Indications for surgery in lateralized PA}

The unquestionable advantage of adrenalectomy over medical treatment consists in the lower long-term economic cost and psychological burden of medication. The disadvantages consist in a greater immediate cost outlay, and in operative risk, which, though low, is undeniable.

Young patients have long-life expectancy and low anesthesiarelated risk, and are thus ideal candidates for surgery. Patients with poor spironolactone tolerance or issues of adherence are also good candidates.

Conversely, older patients have shorter life expectancy and greater surgical risk; they more often present cardiovascular and/or kidney disease requiring ACE inhibitors, angiotensin II receptor blockers, diuretic (including spironolactone) or betablocker treatment. Such treatments will not be stopped, even if hypertension is cured. Likewise, patients who agree to take medication or have a strong aversion to surgery are going to prefer medical management.

Finally, treatment decision-making largely depends on the patient's preferences, and should therefore be taken in common after clear impartial information. 
R6.11 - The decision to operate should be taken in common with the patient after information dealing with at least the following:

- when an adrenal gland nodule is seen on imaging, it is benign, with zero risk of malignant degeneration;

- in the present state of knowledge, medical and surgical treatment are comparable in terms of correcting hypokalemia, lowering blood pressure and preventing cardiovascular and renal morbidity and mortality;

- PA-specific medical treatment is not always well tolerated, and is life-long;

- surgery is possible at any time, including after a trial of medical treatment, in case of unilateral PA (which may need confirmation on adrenal vein sampling);

- surgery generally allows a few drugs to be discontinued (including the PA-specific medication), but antihypertensive treatment has to be continued life-long in more than half of cases.

(Weak, evidence + )

R6.12 - Treatment decision should be discussed prior to adrenal vein sampling, which is pointless in patients unwilling to undergo surgery, and patients should be afforded a medical trial period of a few weeks if they so wish before deciding on surgery.

(Weak, evidence + )

\section{Non-surgical interventions}

Alternatives to surgery for adrenal gland treatment in unilateral PA have been described: cryoablation, thermoablation, embolization, ethanol injection, or radiofrequency ablation. They are less invasive than surgery, but risks and outcomes (notably in the long term) are uncertain. The main contraindications are large ( $>2$ to $4 \mathrm{~cm}$ ) lesions and lesions inaccessible to laparoscopy or in contact with a fragile structure such as the aorta or kidney [10].

R6.13 - Alternative interventions in place of adrenalectomy should be performed only within an assessment study.

(Weak, evidence + )

\section{Disclosure of interest}

The authors declare that they have no competing interest.

\section{References}

[1] Brunt LM. Minimal access adrenal surgery. Surg Endosc 2006;20:351-61, http://dx.doi.org/10.1007/s00464-004-8269-3.

[2] Assalia A, Gagner M. Laparoscopic adrenalectomy. Br J Surg 2004;91:1259-74, http://dx.doi.org/10.1002/bjs.4738.

[3] Constantinides VA, Christakis I, Touska P, Palazzo FF. Systematic review and meta-analysis of retroperitoneoscopic versus laparoscopic adrenalectomy. Br J Surg 2012;99:1639-48, http://dx.doi.org/10.1002/bjs.8921.

[4] Yuge K, Miyajima A, Hasegawa M, Miyazaki Y, Maeda T, Takeda T, et al. Initial experience of transumbilical laparoendoscopic single-site surgery of partial adrenalectomy in patient with aldosterone-producing adenoma. BMC Urol 2010;10:19, http://dx.doi.org/10.1186/1471-2490-10-19.

[5] Hyams ES, Stifelman MD. The role of robotics for adrenal pathology. Curr Opin Urol 2009;19:89-96, http://dx.doi.org/10.1097/MOU. 0b013e32831b446c.

[6] Merseburger AS, Herrmann TRW, Shariat SF, Kyriazis I, Nagele U, Traxer $\mathrm{O}$, et al. EAU guidelines on robotic and single-site surgery in urology. Eur Urol 2013;64:277-91, http://dx.doi.org/10.1016/j.eururo.2013.05.034.

[7] Brandao LF, Autorino R, Laydner H, Haber G-P, Ouzaid I, De Sio M, et al. Robotic versus laparoscopic adrenalectomy: a systematic review and meta-analysis. Eur Urol 2014;65:1154-61, http://dx.doi.org/10.1016/ j.eururo.2013.09.021.

[8] Kaye DR, Storey BB, Pacak K, Pinto PA, Linehan WM, Bratslavsky G. Partial adrenalectomy: underused first line therapy for small adrenal tumors. J Urol 2010;184:18-25, http://dx.doi.org/10.1016/j.juro.2010.03.052.

[9] Fu B, Zhang X, Wang G, Lang B, Ma X, Li H, et al. Long-term results of a prospective, randomized trial comparing retroperitoneoscopic partial versus total adrenalectomy for aldosterone producing adenoma. J Urol 2011;185:1578-82, http://dx.doi.org/10.1016/j.juro.2010.12.051.

[10] Steichen O, Zinzindohoué F, Plouin P-F, Amar L. Outcomes of adrenalectomy in patients with unilateral primary aldosteronism: a review. Horm Metab Res 2012;44:221-7, http://dx.doi.org/10.1055/s-0031-1299681.

[11] Walz MK, Alesina PF, Wenger FA, Deligiannis A, Szuczik E, Petersenn S, et al. Posterior retroperitoneoscopic adrenalectomy-results of 560 procedures in 520 patients. Surgery 2006;140:943-8, http://dx.doi.org/10.1016/ j.surg.2006.07.039 [Discussion 948-50].

[12] O’Boyle CJ, Kapadia CR, Sedman PC, Brough WA, Royston CMS. Laparoscopic transperitoneal adrenalectomy. Surg Endosc 2003;17:1905-9, http://dx.doi.org/10.1007/s00464-002-8878-7.

[13] Quinkler M, Stewart PM. Treatment of primary aldosteronism. Best Pract Res Clin Endocrinol Metab 2010;24:923-32, http://dx.doi.org/10.1016/ j.beem.2010.10.001.

[14] Gill IS, Hobart MG, Schweizer D, Bravo EL. Outpatient adrenalectomy. J Urol 2000;163:717-20.

[15] Edwin B, Raeder I, Trondsen E, Kaaresen R, Buanes T. Outpatient laparoscopic adrenalectomy in patients with Conn's syndrome. Surg Endosc 2001;15:589-91, http://dx.doi.org/10.1007/s004640090021.

[16] Ramírez-Plaza CP, Perales JLG, Camero NM, Rodríguez-Cañete A, Bondía-Navarro JA, Santoyo-Santoyo J. Outpatient laparoscopic adrenalectomy: a new step ahead. Surg Endosc 2011;25:2570-3, http://dx. doi.org/10.1007/s00464-011-1588-2.

[17] Gockel I, Heintz A, Kentner R, Werner C, Wetner C, Junginger T. Changing pattern of the intraoperative blood pressure during endoscopic adrenalectomy in patients with Conn's syndrome. Surg Endosc 2005;19:1491-7, http://dx.doi.org/10.1007/s00464-004-2286-0.

[18] Choi SH, Kwon TG, Kim T-H. Active potassium supplementation might be mandatory during laparoscopic adrenalectomy for primary hyperaldosteronism. J Endourol 2012;26:666-9, http://dx.doi.org/10.1089/ end.2011.0566. 
[19] Fischer E, Hanslik G, Pallauf A, Degenhart C, Linsenmaier U, Beuschlein F, et al. Prolonged zona glomerulosa insufficiency causing hyperkalemia in primary aldosteronism after adrenalectomy. J Clin Endocrinol Metab 2012;97:3965-73, http://dx.doi.org/10.1210/jc.2012-2234.

[20] Chiang W-F, Cheng C-J, Wu S-T, Sun G-H, Lin M-Y, Sung C-C, et al. Incidence and factors of post-adrenalectomy hyperkalemia in patients with aldosterone producing adenoma. Clin Chim Acta 2013;424:114-8, http://dx.doi.org/10.1016/j.cca.2013.05.017.

[21] Küpers EM, Amar L, Raynaud A, Plouin P-F, Steichen O. A clinical prediction score to diagnose unilateral primary aldosteronism. J Clin Endocrinol Metab 2012;97:3530-7, http://dx.doi.org/10.1210/jc.2012-1917.

[22] Amar L, Plouin P-F, Steichen O. Aldosterone-producing adenoma and other surgically correctable forms of primary aldosteronism. Orphanet J Rare Dis 2010;5:9, http://dx.doi.org/10.1186/1750-1172-5-9.

[23] Van der Linden P, Steichen O, Zinzindohoué F, Plouin P-F. Blood pressure and medication changes following adrenalectomy for unilateral primary aldosteronism: a follow-up study. J Hypertens 2012;30:761-9, http://dx.doi.org/10.1097/HJH.0b013e328350225d.

[24] Ghose RP, Hall PM, Bravo EL. Medical management of aldosteroneproducing adenomas. Ann Intern Med 1999;131:105-8.

[25] Marzano L, Colussi G, Sechi LA, Catena C. Adrenalectomy is comparable with medical treatment for reduction of left ventricular mass in primary aldosteronism: meta-analysis of long-term studies. Am J Hypertens 2015;28:312-8, http://dx.doi.org/10.1093/ajh/hpu154.

[26] Strauch B, Petrák O, Zelinka T, Wichterle D, Holaj R, Kasalický M, et al. Adrenalectomy improves arterial stiffness in primary aldosteronism. Am J Hypertens 2008;21:1086-92, http://dx.doi.org/10.1038/ajh.2008.243.

[27] Lin Y-H, Lin L-Y, Chen A, Wu X-M, Lee J-K, Su T-C, et al. Adrenalectomy improves increased carotid intima-media thickness and arterial stiffness in patients with aldosterone producing adenoma. Atherosclerosis 2012;221:154-9, http://dx.doi.org/10.1016/j.atherosclerosis.2011.12.003.

[28] Holaj R, Rosa J, Zelinka T, Strauch B, Petrák O, Indra T, et al. Long-term effect of specific treatment of primary aldosteronism on carotid intimamedia thickness. J Hypertens 2015;33:874-82, http://dx.doi.org/10.1097/ HJH.0000000000000464 [Discussion 882].

[29] Catena C, Colussi G, Nadalini E, Chiuch A, Baroselli S, Lapenna R, et al. Cardiovascular outcomes in patients with primary aldosteronism after treatment. Arch Intern Med 2008;168:80-5, http://dx.doi.org/10.1001/ archinternmed.2007.33.

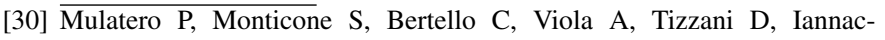
cone A, et al. Long-term cardio- and cerebrovascular events in patients with primary aldosteronism. J Clin Endocrinol Metab 2013;98:4826-33, http://dx.doi.org/10.1210/jc.2013-2805.

[31] Steichen O, Lorthioir A, Zinzindohoué F, Plouin P-F, Amar L. Outcomes of drug-based and surgical treatments for primary aldosteronism. Adv Chronic Kidney Dis 2015;22:196-200, http://dx.doi.org/10.1053/ j.ackd.2014.10.003.
[32] Wu V-C, Kuo C-C, Wang S-M, Liu K-L, Huang K-H, Lin Y-H, et al. Primary aldosteronism: changes in cystatin C-based kidney filtration, proteinuria, and renal duplex indices with treatment. J Hypertens 2011;29:1778-86, http://dx.doi.org/10.1097/HJH.0b013e3283495cbb.

[33] Sechi LA, Novello M, Lapenna R, Baroselli S, Nadalini E, Colussi $\mathrm{GL}$, et al. Long-term renal outcomes in patients with primary aldosteronism. JAMA 2006;295:2638-45, http://dx.doi.org/10.1001/jama.295.22. 2638.

[34] Fourkiotis V, Vonend O, Diederich S, Fischer E, Lang K, Endres S, et al. Effectiveness of eplerenone or spironolactone treatment in preserving renal function in primary aldosteronism. Eur J Endocrinol 2013;168:75-81, http://dx.doi.org/10.1530/EJE-12-0631.

[35] Iwakura Y, Morimoto R, Kudo M, Ono Y, Takase K, Seiji K, et al. Predictors of decreasing glomerular filtration rate and prevalence of chronic kidney disease after treatment of primary aldosteronism: renal outcome of 213 cases. J Clin Endocrinol Metab 2014;99:1593-8, http://dx.doi.org/10.1210/jc.2013-2180.

[36] Catena C, Lapenna R, Baroselli S, Nadalini E, Colussi G, Novello $\mathrm{M}$, et al. Insulin sensitivity in patients with primary aldosteronism: a follow-up study. J Clin Endocrinol Metab 2006;91:3457-63, http://dx.doi.org/10.1210/jc.2006-0736.

[37] Matrozova J, Steichen O, Amar L, Zacharieva S, Jeunemaitre X, Plouin P-F. Fasting plasma glucose and serum lipids in patients with primary aldosteronism: a controlled cross-sectional study. Hypertension 2009;53:605-10, http://dx.doi.org/10.1161/hypertensionaha.108.122002.

[38] Somlóová Z, Widimský Jr J, Rosa J, Wichterle D, Strauch B, Petrák O, et al. The prevalence of metabolic syndrome and its components in two main types of primary aldosteronism. J Hum Hypertens 2010;24:625-30, http://dx.doi.org/10.1038/jhh.2010.65.

[39] Sukor N, Kogovsek C, Gordon RD, Robson D, Stowasser M. Improved quality of life, blood pressure, and biochemical status following laparoscopic adrenalectomy for unilateral primary aldosteronism. J Clin Endocrinol Metab 2010;95:1360-4, http://dx.doi.org/10.1210/ jc.2009-1763.

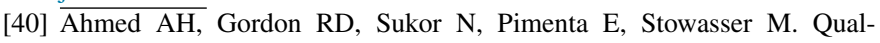
ity of life in patients with bilateral primary aldosteronism before and during treatment with spironolactone and/or amiloride, including a comparison with our previously published results in those with unilateral disease treated surgically. J Clin Endocrinol Metab 2011;96:2904-11, http://dx.doi.org/10.1210/jc.2011-0138.

[41] Sywak M, Pasieka JL. Long-term follow-up and cost benefit of adrenalectomy in patients with primary hyperaldosteronism. Br J Surg 2002;89:1587-93, http://dx.doi.org/10.1046/j.1365-2168.2002.02261.x.

[42] Reimel B, Zanocco K, Russo MJ, Zarnegar R, Clark OH, Allendorf JD, et al. The management of aldosterone-producing adrenal adenomas-does adrenalectomy increase costs? Surgery 2010;148:1178-85, http://dx.doi. org/10.1016/j.surg.2010.09.012 [Discussion 1185]. 